\title{
Teaching NeuroImages: A 48-year-old woman with MELAS
}

Jonah P. Zuflacht, MD, and Antonia N. Pusso, MD

Neurology ${ }^{\circledR}$ 2019;93:e624-e625. doi:10.1212/WNL.0000000000007910

\section{Correspondence}

Dr. Zuflacht

jzuflach@bidmc.harvard.edu

Figure 1 Brain MRI demonstrates a cortically based region of slow diffusion $(A)$ in the right parietal and right temporal lobes with a small area of darkness on apparent diffusion coefficient ( $B$, arrow), which did not correlate fully with the extent of diffusion restriction

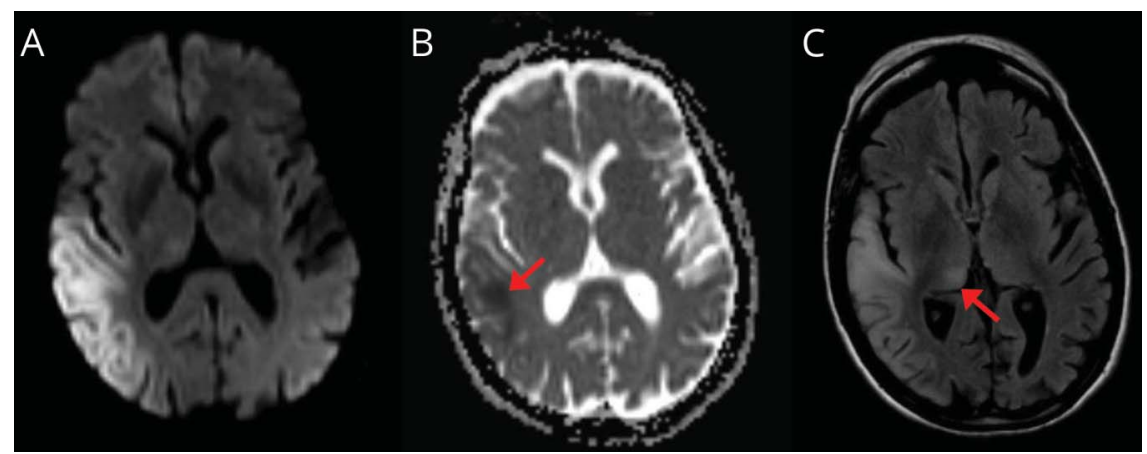

There was corresponding T2 fluid-attenuated inversion recovery (FLAIR) hyperintensity along with mild effacement of the associated sulci (C) In addition, there was abnormal T2 FLAIR signal in the right medial thalamus (C, arrow).

Figure 2 Magnetic resonance spectroscopy (A) within the region of slow diffusion (B) demonstrates an inverted doublet at 1.3 ppm (arrow) consistent with a lactate peak and anaerobic metabolism
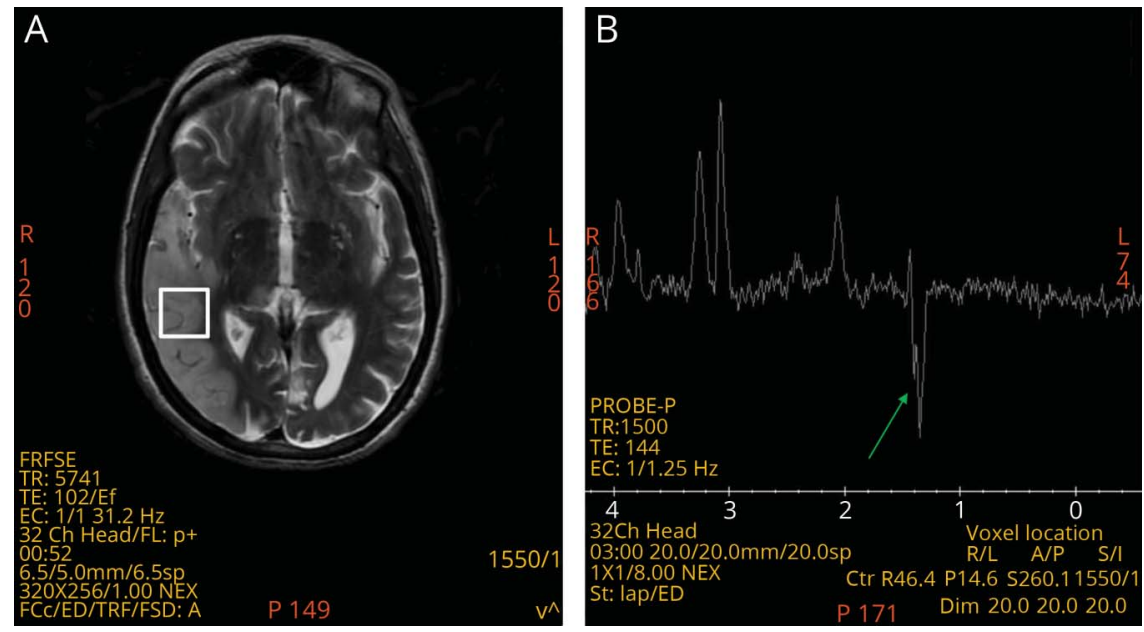

A 48-year-old woman with sensorineural hearing loss and diabetes presented with seizures and headache. She was thin and short-statured. Examination revealed encephalopathy, left homonymous hemianopia, and hemineglect. MRI showed slowed diffusion in right hemisphere, which did not follow a clear vascular distribution and without apparent diffusion coefficient correlate, inconsistent with infarction (figure 1). ${ }^{1}$ Magnetic resonance spectroscopy revealed
MORE ONLINE

$\rightarrow$ Teaching slides

links.lww.com/WNL/

A938

From the Department of Neurology, Beth Israel Deaconess Medical Center, Boston, MA.

Go to Neurology.org/N for full disclosures. Funding information and disclosures deemed relevant by the authors, if any, are provided at the end of the article. 
inversion of lipid lactate peak (figure 2). She had elevated pyruvate but normal lactate. EMG demonstrated myopathy without denervation. Genetic testing showed m.3243A>G pathogenic variant of the MT-TL1 gene. This mutation is found in more than $80 \%$ of patients with mitochondrial myopathy, encephalopathy, lactic acidosis, and stroke-like episodes and always coexists with wild-type DNA. ${ }^{2}$

\section{Study funding}

No targeted funding reported.

\section{Disclosure}

The authors report no disclosures relevant to the manuscript. Go to Neurology.org/N for full disclosures.

\section{Appendix Authors}

\begin{tabular}{|c|c|c|c|}
\hline Name & Location & Role & Contribution \\
\hline $\begin{array}{l}\text { Jonah P. } \\
\text { Zuflacht, } \\
\text { MD }\end{array}$ & $\begin{array}{l}\text { Department of } \\
\text { Neurology, Beth } \\
\text { Israel Deaconess } \\
\text { Medical Center }\end{array}$ & Author & $\begin{array}{l}\text { Designed and } \\
\text { conceptualized case } \\
\text { report, drafted the } \\
\text { manuscript, cared for } \\
\text { the patient }\end{array}$ \\
\hline $\begin{array}{l}\text { Antonia } \\
\text { N. Pusso, } \\
\text { MD }\end{array}$ & $\begin{array}{l}\text { Department of } \\
\text { Neurology, Beth } \\
\text { Israel Deaconess } \\
\text { Medical Center }\end{array}$ & Author & $\begin{array}{l}\text { Designed and } \\
\text { conceptualized case } \\
\text { report, provided key } \\
\text { edits to the manuscript, } \\
\text { cared for the patient }\end{array}$ \\
\hline
\end{tabular}

\section{References}

1. Ito H, Mori K, Kagami S. Neuroimaging of stroke-like episodes in MELAS. Brain Dev 2011;33:283-288.

2. Goto Y, Nonaka I, Horai S. A mutation in the tRNA(Leu)(UUR) gene associated with the MELAS subgroup of mitochondrial encephalomyopathies. Nature 1990;348:651-653. 


\title{
Neurology
}

\author{
Teaching NeuroImages: A 48-year-old woman with MELAS \\ Jonah P. Zuflacht and Antonia N. Pusso \\ Neurology 2019;93;e624-e625 \\ DOI 10.1212/WNL.0000000000007910
}

This information is current as of August 5, 2019

\section{Updated Information \& Services}

\section{References}

Subspecialty Collections

\section{Permissions \& Licensing}

Reprints including high resolution figures, can be found at: http://n.neurology.org/content/93/6/e624.full

This article cites 2 articles, 0 of which you can access for free at: http://n.neurology.org/content/93/6/e624.full\#ref-list-1

This article, along with others on similar topics, appears in the following collection(s):

Metabolic disease (inherited)

http://n.neurology.org/cgi/collection/metabolic_disease_inherited Mitochondrial disorders

http://n.neurology.org/cgi/collection/mitochondrial_disorders MRI

http://n.neurology.org/cgi/collection/mri

SPECT

http://n.neurology.org/cgi/collection/spect

Information about reproducing this article in parts (figures,tables) or in its entirety can be found online at:

http://www.neurology.org/about/about_the_journal\#permissions

Information about ordering reprints can be found online: http://n.neurology.org/subscribers/advertise

Neurology ${ }^{\circledR}$ is the official journal of the American Academy of Neurology. Published continuously since 1951, it is now a weekly with 48 issues per year. Copyright (O 2019 American Academy of Neurology. All rights reserved. Print ISSN: 0028-3878. Online ISSN: 1526-632X.

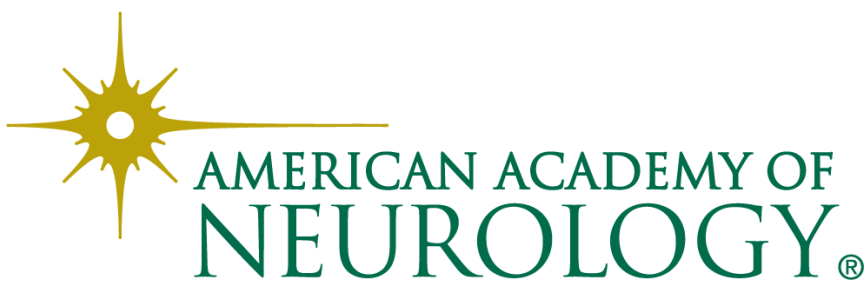

